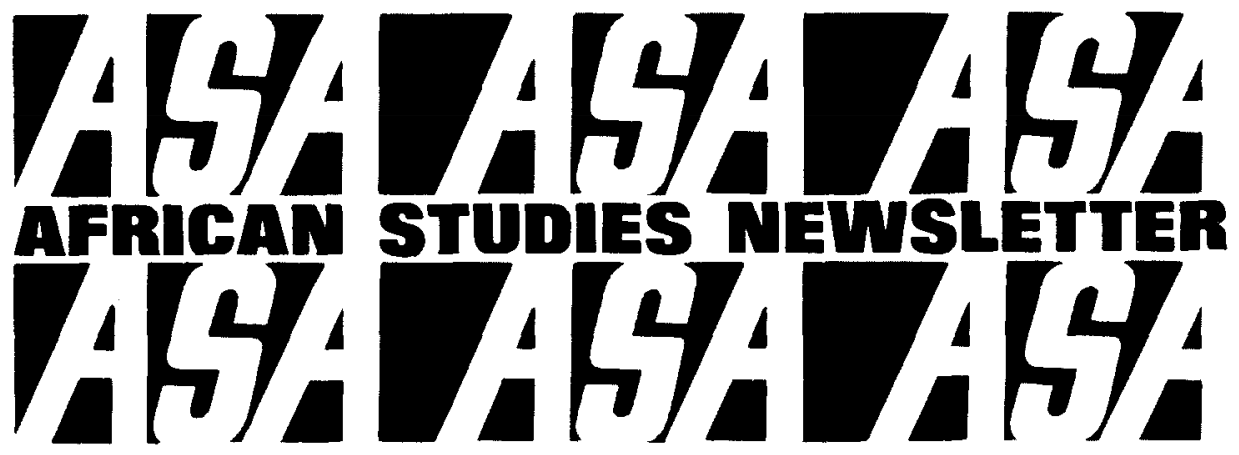

\title{
CONTENTS
}

Annual Report of the Archives-Libraries Committee . . . . . . . 3

Minutes/CAMP Meeting . . . . . . . . . . . . . . 4

American Association of University Professors

List of Censured Administrations . . . . . . . . . . . 5

Nominations for ASA Board of Directors 1980 . . . . . . . . . 8

Candidates' Statements . . . . . . . . . . . . . . 8

Special Announcements ... . . . . . . . . . . . . 9

Meetings . . . . . . . . . . . . . . . . . . . 10

Grants \& Awards . . . . . . . . . . . . . . . . . . 11

Research Opportunities at Makerere

Institute of Social Research . . . . . . . . . . . . 13

Employment . . . . . . . . . . . . . . . 13

Recent Doctoral Dissertations on Africa . . . . . . . . . . . 15

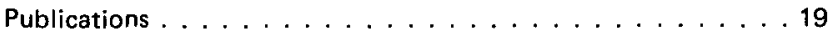

1980 ASA Annual Meeting . . . . . . . . . . . . . . . 27

List of Papers Presented at 22nd Annual Meeting . . . . . . . . 28

Employment Addenda . . . . . . . . . . . . . . . . . . . . . . . . . . 30

In Memoriam-Alan P. Merriam . . . . . . . . . . . 31

Allen Smith has resigned as editor of the African Studies Review. The April issue of the Review will appear in May. Substantial delays may be expected in the appearance of the September and December issues.

\section{TO WHOM IT MAY CONCERN}

Due to the resignation of Alan K. Smith as Editor of the African Studies Review, the African Studies Association is seeking a new Editor and institutional affiliation for the Review. The Association is committed to the efforts of past editors to improve the quality and stature of this journal in the academic community. Articles submitted to the journal are regularly refereed by a panel of recognized scholars.

The African Studies Review is the official journal of the Association with a circulation of 2,000. It is published three times a vear (April, September, and December).

In as much as members of your faculty have demonstrated a strong commitment to African Studies, the Publications Committee felt it would be appropriate to contact you regarding the possible interest of your institution in serving as host and providing a qualified candidate for the position of Editor. The expectations of the Committee are set forth in the attached document. 
If your institution wishes to pursue this possibility, an early response would be greatly appreciated. The Publications Committee will begin consideration of applications in April 1980 and a final decision will be made in the summer of 1980 . Please respond to me at the following address.

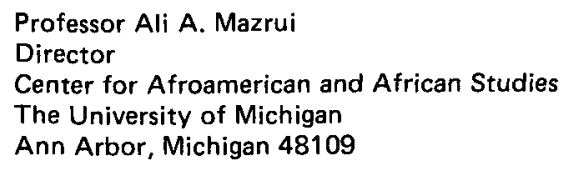

Yours sincerely,

Ali A. Mazrui

Chairman

Publications Committee

African Studies Association

\section{QUALIFICATIONS OF EDITOR AND REQUIRED INSTITUTIONAL SUPPORT}

1. Editors of the Association Publications are appointed by the Board of the African Studies Association and have complete discretionary authority over published material.

A. The appointee should have

- significant Africanist experience and recognized scholarly attainments.

- substantial editorial experience and familiarity with publications programs.

- demonstrated administrative ability.

B. Terms of Service

At the discretion of the Board in consultation with the candidate of the host institution.

11. The Institution should be willing to provide access to the facilities and support services normally accorded professional journals by host institutions including:

- adequate secretarial support and the services of a copy editor.

- released time for the Editor commensurate with duties.

- any additional contribution to the effective production and distribution of the journal.

\section{ARCHIVES-LIBRARIES COMMITTEE AFRICAN STUDIES ASSOCIATION Executive Board, 1979-80}

\section{Chairperson}

Elizabeth A. Widenmann

African Bibliographer

Herbert Lehman Library

Columbia University

New York, N.Y. 10027

(212) $280-3630$

home: (212) 265-8273

\author{
Deputy Chairperson/Chairperson Elect \\ Daniel Britz \\ Bibliographer of Africana \\ Northwestern University \\ Evanston, Illinois 60201 \\ (312) 492-7684
}




\section{Secretary}

Maidel Cason

African Documents Librarian

Northwestern University

Evanston, IL 60201

(312) $492-7684$

\section{Members-at-Large}

Patricia U. Ogedengbe

African Studies Library

Boston University

771 Commonwealth Avenue.

Boston, MA 02215

(617) 353-3726

Joseph J. Lauer

Sahel Documentation Center

Michigan State University Libraries

East Lansing, MI 48824

(517) 355-2366

\section{Onuma Ezera}

Michigan State University Libraries

East Lansing, M1 48824

(517) 355-2366

\section{Ex-Officio}

David Easterbrook

African Studies Area Specialist

Indiana University Library

Bloomington, IN 13210

(812) 337.7511
Beverly Gray

(Library of Congress liaison)

Head, Africa Section

Library of Congress

Washington, D.C. 20540

(202) 287-5528/9

Gretchen Walsh (editor, Africana Libraries News/etter)

Head, African Studies Library

Boston University

771 Commonwealth Ave.

Boston, MA 02215

(617) 353-3726

Gail Grise (chairperson, Cataloging \& Classification sub-committee)

Catalog Dept.

Indiana University Library

Bloomington, IN 47401

(812) 337-7511

Dalvan Coger (chairperson, Bibliography sub-committee)

Dept. of History

Memphis State University

Memphis, TN 38152

Daniel Britz (chairperson, CAMP)

see above for address

\section{ANNUAL REPORT OF THE ARCHIVES-LIBRARIES COMMITTEE, 1978-79}

The Archives-Libraries Committee has completed another year of active service to the Association and, we believe, to the wider community of Africanists as well. Four major areas of Committee activities during this past year are as follows: 1 . Our Subcommittees have continued to be particularly active in two areas of great concern, Cataloging and Classification and Bibliography. The Subcommittee on Cataloging and Classification has continued to relate the needs of Africanists here and abroad to the practical matters of cataloging and classification within the library profession. Both the continuing dialog which has been established with the Library of Congress and the representation accorded to Africanists this year on two very important cataloging committees within the American Library Association attest to the strength and importance of Africanist concern. The Bibliography Subcommittee has continued to offer its services as a clearinghouse for proposed Africana bibliographic projects. Also, much of the year's activities has focused on the establishment and implementation of the first Conover-Porter Award. 2. At our two Committee meetings this year, we have attempted, in addition to carrying out Committee business, to provide opportunities for presentations and discussions of library-related interest. At Northwestern University in April, we learned about outreach as defined by the Office of Education and how this relates to Africanist librarians. In addition, we saw a detailed demonstration of the automated Northwestern Africana cataloging project. In Los Angeles, we were able, working through the USICA and the IIE, to bring two African government archivists to present papers at the Committee's panel, "African Government Archives and the Expatriate Researcher." As usual, we invited a large number of local librarians to join with us at our meetings so that we might increase our contacts with institutions having African interests but lacking an Africana specialist in their libraries. 3. We have communicated two statements of concern to the President's Commission on Foreign Language and International Studies regarding the development of Area Studies resources and are gratified with the positive response we have 